\author{
Shala Barczewska, Agata Andreasen \\ Department of History and Culture Studies, Institute of Foreign Languages, Jan Kochanowski \\ University, Kielce, Poland \\ shadanielle@gmail.com
}

\title{
Good or marvelous? Pretty, cute or lovely? Male and female adjective use in MICASE
}

\begin{abstract}
Nearly half a century after Lakoff's controversial publication Language and a Woman's Place (1975), the verdict is still out as to the exact relationship (if any) between language and gender (cf. Baker 2014: 3, Cameron 2005). The proposed theories addressing the similarities and differences between male and female speech often focus on social and cultural influences that may cause a man or woman to act or speak in a certain way; for example, use more adjectives or a broader variety of adjectives. Moreover, they often use as their source materials anecdotes and personal data. As a result, the studies, and the papers they produce, are often influenced by researcher intuition (Baker 2014; Schmid 2003). Only within the last fifteen to twenty years has it really been possible to analyze large collections of spoken data to test this intuition. Nevertheless, even with the advent of computer-assisted data analysis, the results are ambiguous. The aim of our study is to analyze male and female use of adjectives in the Michigan Corpus of Academic Spoken English (MICASE). We compare the use of select basic adjectives (good, bad, big, small, pretty, ugly, important, and different) and their near synonyms in an attempt to support or call into question intuition-based claims that certain adjectives are more 'feminine' or 'masculine', or that women use more and a greater variety of adjectives than men. This paper hopes to contribute to the ongoing discussion regarding gender differences and language.
\end{abstract}

\section{Introduction}

As Baker (2014: 3), Cameron (2005) and others have mentioned, scholars are divided when it comes to determining the influence gender has on language use. Theories addressing the similarities and differences between male and female speech often focus on social and cultural influences that may cause a man or woman to actor speak in a certain way; for example, claims that women use more ad- 
jectives or a broader variety of adjectives than men do. As a result, these studies are often influenced by researcher intuition. Only within the last fifteen to twenty years has it really been possible to analyze large collections of spoken data to test this intuition (Baker 2014; Schmid 2003). Nevertheless, even with the advent of computer-assisted data analysis, the results are ambiguous. The aim of our study is to analyze male and female use of adjectives in the Michigan Corpus of Academic Spoken English (MICASE) against some of the prevailing theories.

There are a variety of perspectives when it comes to understanding sex and gender. Most simply, gender is as "the social elaboration of biological sex. Gender builds on biological sex, it exaggerates biological difference" (Eckert and $\mathrm{McCo}$ nnell-Ginet 2002: 8). Queen (2013: 368) defines gender as a social category which manifests itself in interactions and is contingent on complex factors such as institutions, social values or cultural rules. Schilling-Estes and Wolfram (1998:185) see gender as functioning in a way similar to social class as both constitute social determinants. Tannen (1990) views different genders as different cultural groups with different communication styles. The term sex, on the other hand, typically refers to biological aspects and anatomical features of the human body. However, in the literature, these terms are often used interchangeably to simplify communication (cf. Paoletti 2012: 2).

The process of developing one's own way of behaving is complex. According to Wardhaugh (2006; Chambers and Schilling-Estes 2013), men and women do not develop their communicative habits based on their linguistic competence alone. The author claims that male and female performance may depend on their occupation or social position. Gender identity is also shaped through interaction and participation in various communities. Moreover, as Wardhaugh (2006) points out expectations regarding male and female behavior changes with each generation and depends on race, ethnicity, social class, and religion. For these reasons, gender should be studied in each generation anew.

Thus, while the starting point is biological, theories addressing the similarities and differences between male and female speech often focus on social and cultural factors that may cause a man or woman to actor speak in a certain way. This is not to say that the scientific community has reached a consensus as to whether or not these differences exist. Among those who argue for gender differences in language are Lakoff $(1973 ; 1975)$ and Tannen (1990). Opponents of this dichotomy include Cameron (2005; 2008), MacGeorge et al. (2004) and Hyde (2005). Others are hesitant to take a firm stand either way, but suggest caution, arguing, among other things, that culture and other social influences also have an impact on speech, and that influence may be stronger than gender (e.g. Baker 2014; Gu 2013).

One of the frequently mentioned areas in which men and women are supposed to differ is in their choice and use of adjectives. Women are said to use a greater variety of adjectives with more frequency; moreover, certain adjectives are said to belong primarily to the female domain. According to Lakoff (1973), women are 
more frequent users of adjectives such as fantastic, lovely, sweet, cute, precious, awful, pretty, nice, charming, wonderful, dreamy, adorable, and divine. Men, on the other hand, are said to prefer basic adjectives, such as good or bad.

The organization of our paper proceeds as follows. In Section 2, we present some of the issues and theories of the connection - or lack thereof - between gender and language use and describe some of the research that has been conducted to date. In Section 3, we explain our research methodology as well as our reasons for choosing the MICASE corpus. In Section 4, we present the results of our analyses in a series of tables followed by discussion. In the conclusion, Section 5 , we discuss the implications of this study and possible future research.

\section{Language use and gender}

This section looks at a variety of approaches to studies in gender and language from both a theoretical and practical perspective. Section 2.1 presents different understandings of gendered language - including whether or not such a feature of language exists. Section 2.2 describes some of the studies that have been carried out to test these theories.

\subsection{Proposed reasons for differences in male/female speech patterns}

Several theories have been proposed to explain possible differences between male and female speech. Although Vandergriff (1984) claims that interest in this subject can be traced back to 1582 and Haas (1979) cites studies from 1922, it is commonly accepted that the intersection between language and gender became an object of study in sociolinguistics in the mid-1970s. Robin Lakoff's Language and a Woman's Place, published in 1975, which was an extension of her 1973 article of the same title, is said to have not only introduced the concept of studying gender within linguistics but also within other disciplines as well (Bucholtz 2004: 3). She emphasizes the social significance of gender and distinguishes between features of male and female speech patterns, and the ideas discussed in that seminal work continue to inspire sociolinguistic research, including this study.

\subsubsection{The dominance approach}

For Lakoff (1973; Lakoff 1975), the language men and women use represent power and social codes; hence, her approach is now referred to as the 'dominance' approach to language and gender (cf. Baker 2014). Accordingly, the differences between female and male language use are seen as emerging from hierarchical organization and inequality of society, in which women tend to be subordinate to men. As she explains, this view of language and gender was a product of the spirit of the equal rights movement, during which language began to be analyzed in terms of social identities (Lakoff and Bucholtz 2004). This perspective still influences re- 
search and has been continued by organizations such as the International Gender and Language Association (IGALA) and the Berkeley Women and Language Group (BWLG), which were founded in the 1990s (Queen 2013: 370-371). The former focuses on the correlation between language and gender, while the latter focuses on the interdisciplinarity of gender studies and language. This phenomenon goes beyond linguistics and can be found in a variety of other disciplines, e.g. psychology, philosophy, literature, history, religious studies, politics, cultural and media studies, or even in law and management (Bucholtz 2004:3).

Differences in female language observed by Lakoff (1973) include a greater variety of adjectives, preference for words such as cute and lovely, preference for euphemisms over taboo language, more frequent use of hedges and polite language.

\subsubsection{The gender differences model}

A student of Lakoff, Deborah Tannen (1990) calls for a shift in focus from a power dominance model to a 'gender differences' model. Tannen (18) argues that ' $\mathrm{t}$ ] he effect of dominance is not always the result of an intention to dominate.' Instead, these linguistic behaviors that appear domineering may result from a difference in styles of communication and interaction learned during childhood.

Even if they grow up in the same neighborhood, on the same block, or in the same house, girls and boys grow up in different worlds of words. Others talk to them differently and expect and accept different ways of talking from them. Most important, children learn how to talk, how to have conversations, not only from their parents but from their peers. (43)

Specifically, boys' relationships focus on hierarchical structures. Status is gained and lost based on one's (in)ability to give orders, tell jokes, and win at the games they play. Conversely, girls' play usually occurs in smaller groups, perhaps with a best friend. Closeness and feeling accepted are prioritized and most girl games, as identified by Tannen (e.g. jump rope or playing house) do not have winners. As a result, she claims: 'If adults learn their ways of speaking as children growing up in separate social worlds of peers, then conversation between women and men is cross-cultural communication' (47). Hence, in her work she applies theories and observations from inter-cultural studies.

This seems to coincide with ideas put forth in the 'prestige-based' theory of gender differences. Schilling-Estes and Wolfram (1998: 188-192) describe this approach as explaining language differences by an assumption that women, more than men, use language to maintain or gain social prestige. In part, this is said to be due to the different roles men and women fill in society. However, Schilling-Estes and Wolfram express doubt regarding this theory. Not only do they cite disparate research, but they also chart other variables that affect the differences in 'presti- 
gious' linguistic choices, such as class and profession. For example, male blue-collar workers power was achieved rather through the use of vernacular forms as they gained success through physical work rather than through negotiating Holmes (1997) claims that women may be linguistically more flexible than men due to the desire for prestige.

Another explanation is a desire to appear masculine or feminine. According to Wolfram and Schilling-Estes (1998: 187, 189), men tend to use more sub-standard vocabulary as it makes them masculine. Women who express this trait may be considered less feminine. Consequently, social expectations greatly affect the linguistic patterns used by both sexes. It is worth indicating that the way of speaking reflects social identity and there are strict rules regarding gender language.

\subsubsection{Post-structuralist paradigm}

Cameron (2005) distinguishes between two main approaches to linguistic gender: a modern feminist approach and a postmodern feminist approach. According to the former, gender is built on the basis of biological sex. This approach assumes that men and women comprise two different homogeneous categories that each possess gender identities and gender-related linguistic codes of conduct, which are developed during their early stages of life. In view of the modern approach, gender is something that everyone possesses, as opposed to the postmodern approach, which perceives gender as something that people perform (Butler 1990). From the postmodern point of view, sex is not a natural feature; it is constructed. Consequently, proponents believe that individuals assume male or female characteristics and identity depending on their social environments. For example, Eckert \& McConnell-Ginet (2002) cite the claim that men and women tend to be more categori$\mathrm{cal}$, success-oriented and sometimes even aggressive as the result of socialization. Thus, they argue, gender is determined by a complex array of social factors, rather than by biological sex alone. The process starts from the very beginning when a child is born and gets a name attributed to their sex. There are then introduced to gender expectations created by society, for instance, pink clothing for girls and blue for boys. ${ }^{1}$

Despite the fact that both women and men learn certain sex-related behaviors as participants in a gendered society, the postmodern view seems to be lacking because it minimizes the role sex plays in gender identity. For the purposes of this paper, gender is identified on the basis of biological sex, but this does not ignore the influences of the socio-cultural environment, expectations, etc.

1 It is worth emphasizing that these social expectations change over time. For example, the above-mentioned use of pink for girls and blue for boys, which now seems natural, is a relatively recent phenomenon (cf. Paoletti 2012). 


\subsubsection{The role of cultural environments and upbringing}

Wolfram and Schilling-Estes (1998: 203) point out that socialization is crucial in children's development. During the age when children acquire language skills, girls and boys also learn certain contrasting linguistic patterns. As a result, apart from learning gender-related activities, they also learn gender-specific language behavior. Thus, differences in language patterns between both sexes are established early on and have a huge impact during social interactions in the later stages of their life.

One explanation for distinct ways of communication may be that children usually acquire their language and code of behavior in single-sex peer groups. Herring and Kapidzic (2015) and Tannen (1990) notice that the social context in which children's play occurs differs according to gender. For example, they claim that boys favor larger groups with hierarchical ordering. From a pragmatic point of view, boys' speech seems to be more authoritative, while girls tend to be more agreeable. Tannen (1990) observes that males learn how to combat and gain status through negotiating. Their games have rules often established during the process of arguing. Adolescent males are also apt to boast about their achievements and skills. Adolescent girls, on the contrary, prefer smaller groups or pairs. Their main goal is to establish a friendship based on intimacy. They do not tend to boast or give direct orders. This is replaced by acceptance and making suggestions. Their expressions are polite and signal that they want to emphasize with the audience. Tannen emphasizes that these differences do not mean that men value close relationships less, simply that they have different ways of developing and maintaining them.

\subsubsection{Gender similarities}

At the early stages of gender studies, the disparities between women's and men's speech were regarded as biologically conditioned. Wolfram \& Schilling-Estes (1998) claim that this view was undermined later when scholars observed that biological sex in and of itself has nothing to do with this dichotomy. At the same time, biological differences result in gender-differentiated language (Wardhaugh 2006). In other words, the differences are not innate, but because of the sex one is born with, individuals are raised to speak and act according to social conventions. It is debatable whether cross-sex language patterns emerge from the access to political, economic and social power, or from various social roles and the process of socialization. This question was also raised by the popular debate called 'difference vs. dominance' during the 1980s and 1990s. However, as Cameron (2005: 486) observes, in hindsight, these two positions do not differ so much as they both treat gender norms, in terms of how men and women speak, as a product of society. Moreover, they also viewed the groups of male and female as 'well defined and internally homogeneous' (Cameron 2005: 486). As recent research has shown (cf. Amir et al. 2012; Baker 2014), while there are tendencies for male and female language use, there is also great variation within each gender. 
Others, such as Cameron (2008) and Hyde (2005), disagree with Lakoff completely. Hyde (2005) proposes the 'gender similarities hypothesis' and argues that in nearly all aspects, males and females are alike in more ways than they differ. Cameron (2005) argues that Lakoff's essay was written many years ago and the way females speak has changed. Moreover, she argues that Lakoff's assumptions were based on intuition rather than scientific evidence. In her book, Cameron (2008) presents opposing views supported by research carried out by Judith Baxter in groups of 14-15-year-old school pupils. In Baxter's study, no dissimilarities in cooperativeness vs. competitiveness between boys and girls were observed. Both female and male speech included cooperative and competitive elements. Since this distinction is the basis for many theories of gender and language, it does indeed call the foundation of these theories into question.

Baker (2014) draws attention to the fact that an expectation of differences may bias not only the way the results are described but also the very way in which a study is designed. For example, he highlights the problem of keyword analysis, which by nature extracts differences, while ignoring or hiding similarities (2014: 24). He also points out that it is also important to recognize the context in which the data was collected. In particular, he mentions the BNC, in which male language primarily comes from professional settings and female language from domestic settings (2014: 29-30)

Gu's (2013) position is more one of caution than outright rejection of either the gender differences or gender dominance position. The author claims that, besides their gender-based 'sub-cultures', both women and men:

(...) still have their national culture, which make them belong to the same nation. Whether males or females, on one side, they form their values and way of behavior within their national culture; on the other side, they have their own values and way of behavior within their subculture. So their behavior, including language behavior must have differences and similarities. (2013: 251)

Thus, not only are speech patterns influenced by gender, but they are also influenced by national and ethnic cultures. Hence, it is necessary to use caution when talking about how men and women use language to communicate as this may lead to inaccurate generalizations. In looking at gender and language it is important to control for content and be aware of national and ethnic culture. Moreover, it is also important to look at similarities.

To summarize, although female and male speech styles seem to differ to some extent, they may also share many similar characteristics. According to Baker (2014), similarities are often overlooked in gender studies because of a drive to produce differences. Moreover, generalizations may be stereotypical and do not appear to apply equally to all women and men. Additionally, attitudes to gender-related speech patterns are changing over time. For these reasons, gender issues should be studied in each generation anew. 


\subsection{Previous studies connecting language and adjective use}

Studies in language and gender abound, although, as Baker (2014) and Schmid (2003) observe, much of this research is conducted using small amounts of data focused on qualitative rather than quantitative results. Here we will briefly present a few studies conducted in the 1970s and after the popularization of the tools of corpus linguistics.

Hass (1976: 621) mentions four studies conducted in the 1970s, i.e., around the time of Lakoff's seminal publication, that compare adjective use by men and women with differing results. Hartman (1976) analyzed interviews with men and women in Maine who had been born around 1900. Her results confirmed some of Lakoff's hypotheses; namely, that women use more "feminine" words than men, e.g., lovely, delightful, wonderful, nice, pretty (12) and that women's language is 'more "evaluative-flowery," more polite, more tentative, more qualified' (13). Two other studies with younger participants produced similar results: Brandis and Henderson (1970) analyzed the spoken language of 5-year old British children, whereas Entwisle and Garvey (1972) looked at written stories of ninth-graders. Both found that females used more adjectives than their male counterparts. However, not all studies from that time period were in agreement. Kramer's (1974) study of linguistic variation in written descriptions of black and white photographs by college students revealed no gender-based difference in the frequency or type of adjectives or-ly adverbs.

Although these studies are interesting, they are all small-scale and dated. Now that we have the option of using corpora, one would expect these questions of gender differences, particularly when it comes to the frequency of certain adjectives or -ly adverbs, which can be retrieved from computer programs with relative ease, to have been answered. However, research in this area is still wanting. As an example of this, Baker (2014: 6) notes that he could only find four papers that applied corpus-linguistics methodology out of the 63 published in the journal Gender and Language between 2007 and 2012. Granted, he found other articles that used the word corpus, but the studies turned out to have been conducted manually and were more qualitative than quantitative in nature.

Schmid (2003) undertook one of the first broad, corpus-based analyses of gender differences in spoken British English. He analyzed a series of claims made by Lakoff (1975) and others, including hedging, adjectives, and semantic domains. His results seemed to confirm many of Lakoff's intuitions. For example, he found that females use more 'women's words', more hedges, and more tag questions than men. Specifically, he notes the high frequency of lovely and the difficulty with pretty, which will be discussed in our analysis. However, as Baker (2014: 29-30) observes, these results may have been skewed by the types and locations of conversations recorded for either gender.

Bamman et al. (2014) study Twitter use and notice that many language patterns appear to agree with expectations put forth in the literature; e.g., women use 
more words related to emotion and men use more words related to technology. However, not all of their data aligned with the stereotypes; e.g., for many of the grammatical markers there was no statistical difference. Moreover, they observed other factors that influenced language use beyond the binary categories of male/ female.

In their study of adolescent bloggers, Huffaker and Calvert (2005) find girl bloggers to be no more polite or passive than their male counterparts. Moreover, they note that men used more emoticons, i.e. emotional 'language', than their female counterparts, which contradicts what the literature suggests we should find. This could be because language is constantly changing, as suggested by Cameron (2005); alternatively, this could be because of the intuitive nature of Lakoff's first publication or the anonymity provided by the internet.

Amir et al. (2012) studied posts over the span of a year for four teenage Malaysian bloggers writing in English (two male and two female). One of the areas they looked at was the frequency of so-called 'empty adjectives', including those mentioned by Lakoff (1973)as 'women's words.' Although both male and female bloggers in Amir et al.'s study used these adjectives, they were definitely favored by the females.

In analyzing taboo language among adults and children ages one to twelve, Jay and Jay (2013) found that differentiation according to gender occurred after the children reached five years of age, that is, after they entered school. For the most part, both boys and men exhibited a greater taboo lexicon which they used more frequently than women. The one exception is girls ages $3-4$, which produced more taboo language than the boys their age. As a result, Jay and Jay conclude that, from the earliest stages of childhood, girls and boys learn certain speaking patterns through social interactions. They suggest that this begins when a child enters different social environments, such as school, in which they spend time with samesex peers and begin to take on gender norms.

\subsection{Summary}

Although a great number of scholars highlight the differences between women's and men's speech patterns, there are studies which call into question the conclusion of differentiating between female-male styles of communication. Our study focuses on one area of this discrepancy: the use of adjectives. Lakoff (1973; 1975), (Brandis and Henderson 1970; Entwisle and Garvey 1972), Hartman (1976), Bamman et al. (2014), Schmid (2003) and Amir et al. (2012) argue that adjective use differs between the sexes, whereas Kremer (1974), and Cameron (2008) claim that it does not, and Bamman et al. (2014)'s study seems to suggest that not all differences align with the stereotypes as men may be equally, if not more, expressive than women. Baker (2014) is hesitant to come down strongly in support of either position. Since it cannot be clearly stated which claims about male/female speech patterns are best supported by the data, more corpus-based analysis is 
needed. The paper presents the results of a study carried out with the use of the Michigan Corpus of Academic Spoken English (MICASE). Section 3 describes the method we employed and is followed by our analyses.

\section{Method}

What can be concluded from the research described above is that it has produced conflicting results. One of the reasons for this is that the scholars were sometimes extrapolating from experience or using their intuition rather than linguistic data. This is in part due to the fact that only relatively recently have we developed the tools to collect and analyze large bodies of language. Even with having these tools, it is often easier to access, and hence analyze works of fiction than real, impromptu conversations. While such analysis tells us how writers believe we speak, and of course, must be convincing or the show will lack an audience, it is still based on perception as opposed to real language in use. Another problem that has been revealed is that real language data may have been gathered from different contexts, thereby eliciting different types of language. According to Baker (2014: 29), this is one of the problems with using the spoken $\mathrm{BNC}$ to analyze gendered language: data for male speech was largely gathered in the workplace, whereas data for female speech was largely gathered in the home or domestic settings. Hence, Schmid (2003)'s conclusions that women use more words describing the home and domestic activities than men may be the result of context rather than gender.

Of the many questions that could be asked, this paper focuses on one that keeps reappearing in the literature: do women tend to use more and a wider variety of adjectives than men? Do they really prefer pretty and cute and lovely over their male counterparts? If we are to answer these questions, we not only need real language data that has been tagged according to gender, but we also need language that is produced in the same context, so as to rule out other variables. While there are currently many online-corpora available for linguistic analysis, few distinguish between the sex of the speakers. For this reason, the Michigan Corpus of Academic Spoken English (MICASE) was used. It enables us to select for gender (male/female) and focus solely on English used in one context: the American university.

\subsection{MICASE Corpus}

The Michigan Corpus of Academic Spoken English (MICASE) (Simpson et al. 2002) is a collection of transcripts of academic speech events collected by the English Language Institute at the University of Michigan in Ann Arbor from 1997 to 2002. ${ }^{2}$ It includes 152 transcripts totaling approximately 1.85 million words from college life across a variety of disciplines and events (see Figure 1 and Table 1 ).

2 The best online description of MICASE is Römer (2010), as the interface itself is no longer maintained and many links intended to provide information about the corpus do not work. 

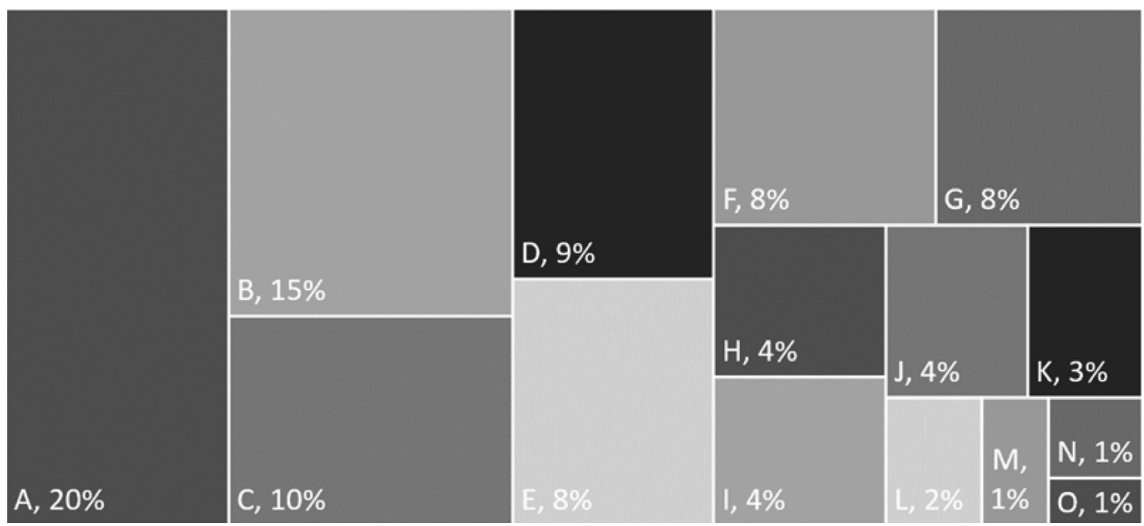

Figure 1 Speech events in MICASE (according to data provided by Römer 2010)

\begin{tabular}{|llll}
\hline Letter & Type of speech event & Letter & Type of speech event \\
A & Small Lectures & I & Labs \\
B & Large Lectures & J & Meetings \\
C & Office Hours & K & Dissertation Defenses \\
D & Colloquia & L & Advising \\
E & Student Presentations & M & Service Encounters \\
F & Seminars & N & Tours \\
G & Study Groups & O & Interviews \\
H & Discussion Sections & & \\
\hline
\end{tabular}

Table 1 Key to Figure 1

The MICASE interface allows the research to select for a variety of variables including type of interaction, student/faculty, English language fluency and gender. Non-native speakers of English are not excluded from the corpus and represent approximately $12 \%$ of the speakers (Römer 2010); thus, this project, despite using a corpus created in the US has an international flavor (cf. Swales 2006).

The choice to use MICASE was determined by several factors. First, it is one of the only, if not the only, freely available online corpus interface that enables the researcher to select for gender. Secondly, the corpus contains a large database from a variety of genres of speech with natural conversations of men and women in academia, both inside and outside the classroom, in formal and informal settings. Thirdly, different generations and academic levels are represented: faculty (49\%), undergraduate students (22\%) and graduates (22\%). Finally, as Römer (2010) highlights, efforts were taken to collect roughly the same amount of male and female texts for each genre and discipline. ${ }^{3}$ As a result, it does not run up against the same

3 Communication events at the professional departments (e.g. law or medicine) were not included. 
problem as the $\mathrm{BNC}$, mentioned above, in which different genders are primarily recorded in different contexts (cf. Baker 2014). That said, despite efforts on the part of the corpus's compilers, there are more words spoken by females in all categories described above as they represent $54 \%$ of MICASE (909,053 words), whereas men represent $46 \%$ ( 786,487 words). 4

\subsection{Procedure}

To answer the first question, eight basic adjectives were chosen, and their near synonyms were collected with the aid of Thesaurus.com. These adjectives can be found in Table 2.

The study of these near synonyms makes it possible for us to check the claim that women use more elaborate adjectives than men and/or a greater variety. Each synonym in Table 2 was concordanced in MICASE, but only those near synonyms which occurred at least twice are analyzed in the sections that follow.

\begin{tabular}{|l|l|}
\hline Adjective & Near synonyms \\
\hline good & $\begin{array}{l}\text { acceptable, fine, excellent, exceptional, favorable, great, marvelous, } \\
\text { positive, satisfactory, wonderful }\end{array}$ \\
\hline bad & $\begin{array}{l}\text { atrocious, awful, crummy, dreadful, lousy, unacceptable, rough, } \\
\text { poor, horrible, wrong }\end{array}$ \\
\hline big & $\begin{array}{l}\text { large, great, colossal, considerable, enormous, gigantic, sizable, } \\
\text { huge, massive, tremendous }\end{array}$ \\
\hline small & $\begin{array}{l}\text { tiny, cramped, limited, meagre, microscopic, miniature, minuscule, } \\
\text { modest, slight, short }\end{array}$ \\
\hline pretty & $\begin{array}{l}\text { beautiful, charming, elegant, good-looking, graceful, handsome, } \\
\text { lovely, neat, attractive, cute }\end{array}$ \\
\hline ugly & $\begin{array}{l}\text { awful, grisly, hideous, horrid, unseemly, unsightly, disgusting, terri- } \\
\text { ble, gross, unpleasant }\end{array}$ \\
\hline important & $\begin{array}{l}\text { unlike, dissimilar, disparate, distant, distinctive, divergent, offbeat, } \\
\text { contrasting, distinct, various }\end{array}$ \\
\hline $\begin{array}{l}\text { essential, valuable, decisive, extensive, far-reaching, imperative, } \\
\text { meaningful, critical, crucial, significant }\end{array}$ \\
\hline
\end{tabular}

Table 2 The adjectives and their near synonyms analyzed according to the MICASE

In the section that follows we present the frequency with which men and women are recorded using these words in the MICASE corpus and discuss how these results conform to or contradict previous studies. We pay particular attention to the use of 'women's words', i.e., so-called empty adjectives, and preference for near synonyms over basic adjectives.

4 This totals less than the 1.87 million mentioned on the MICASE website. The most likely explanation for this is that the remaining words belong to the unknown category. 


\section{Results and Analysis}

In this section, the distribution of the adjectives used by men and women according to MICASE is analyzed. As mentioned in the previous section, the basic adjectives studied here are good, bad, big, small, pretty, ugly, different, important. For each, near synonyms were collected from Thesaurus.com. In the sub-sections that follow, the frequencies of each basic adjective and its near synonyms as used by males and females are presented and discussed. Normalized values that are higher for each pair are shaded in grey, while those uses that are statistically significant have been bolded.

\subsection{Good and bad}

This section looks at the use of good and bad and their near synonyms: great, fine, wonderful, excellent and wrong, poor, awful, horrible, respectively. The number of occurrences of each adjective in MICASE according to gender is presented in Table 3 , along with the $\mathrm{p}$-value suggesting the statistical significance of any observed differences.

\begin{tabular}{|c|c|c|c|c|c|}
\hline \multirow[t]{2}{*}{ Adjective } & \multicolumn{2}{|l|}{ Males } & \multicolumn{2}{|c|}{ Females } & \multirow[t]{2}{*}{ P-value } \\
\hline & \begin{tabular}{|l|} 
per \\
1000
\end{tabular} & $\begin{array}{l}\text { raw } \\
\text { frequency }\end{array}$ & \begin{tabular}{|l|} 
per \\
1000
\end{tabular} & $\begin{array}{l}\text { raw } \\
\text { frequency }\end{array}$ & \\
\hline good & 988 & 1.256 & 1344 & 1.478 & 0.0001 \\
\hline great & 312 & 0.397 & 423 & 0.465 & 0.0324 \\
\hline fine & 164 & 0.209 & 258 & 0.284 & 0.0019 \\
\hline wonderful & 40 & 0.051 & 63 & 0.069 & 0.1236 \\
\hline excellent & 18 & 0.023 & 38 & 0.042 & 0.0324 \\
\hline favorable & 3 & 0.004 & 1 & 0.001 & 0.2501 \\
\hline satisfying & 1 & 0.001 & 4 & 0.004 & 0.2380 \\
\hline marvelous & 12 & 0.015 & 4 & 0.004 & 0.0214 \\
\hline Total 'good' & 1522 & 1.935 & 2126 & 2.339 & 0.0001 \\
\hline $\begin{array}{l}\text { Near synonyms } \\
\text { total }\end{array}$ & 550 & 0.683 & 791 & 0.861 & 0.0001 \\
\hline bad & 209 & 0.266 & 228 & 0.251 & 0.5485 \\
\hline wrong & 222 & 0.282 & 201 & 0.221 & 0.0121 \\
\hline poor & 62 & 0.079 & 99 & 0.109 & 0.0455 \\
\hline awful & 20 & 0.025 & 20 & 0.022 & 0.6455 \\
\hline horrible & 14 & 0.018 & 25 & 0.028 & 0.1902 \\
\hline Total 'bad' & 527 & 0.670 & 573 & 0.630 & 0.3125 \\
\hline $\begin{array}{l}\text { Near synonyms } \\
\text { total }\end{array}$ & 318 & 0.404 & 345 & 0.380 & 0.4122 \\
\hline
\end{tabular}

Table 3 The frequency of good, bad and their near synonyms used by males and females according to the MICASE 
The first thing that we notice in looking at this table is that females use most of the positive adjectives analyzed more frequently, and, in many cases, this difference is statistically significant. Moreover, this includes words at both ends of the intensity spectrum, from fine to great and excellent. Marvelous here stands out: we would expect it to be a predominantly female adjective; however, in the MICASE it is not only used more frequently by male speakers, but this difference is statistically significant ( $\mathrm{p}=0.0214)$. Conversely, when it comes to bad and its near synonyms, we see that men use these words comparatively more often than females. While as a set, the difference is not statistically significant $(\mathrm{p}=3.125)$, wrong does stand out as statistically more frequent among men than women $(\mathrm{p}=0.0121)$. At the same time, poor and horrible are the only two negative adjectives listed that are favored by women, and only the former is statistically significant ( $\mathrm{p}=0.0455$ and 0.1902 , respectively).

This brings us to the third observation: within MICASE, occurrences of good, and its near synonyms, far outnumber occurrences of $\mathrm{bad}$, and its near synonyms. The positive adjectives listed here (3648 instances for both males and females) occur 3.61 times more frequently than the negative ones (1010 instances for both males and females). In order to evaluate whether this is unique to MICASE or unique to academic English, a comparison was made with the different subsections of COCA: The Corpus of Contemporary American English (Davies 2008-). Table 4 presents the proportion of the words good vs. bad in the COCA sub-corpora.

\begin{tabular}{|l|l|l|l|}
\hline Corpus & good(/1,000) & bad $(\mathbf{1}, \mathbf{0 0 0})$ & Proportion \\
\hline MICASE & 1.262 & 0.24 & 5.336 \\
\hline MICASE (men) & 1.256 & 0.266 & 4.722 \\
\hline MICASE (women) & 1.478 & 0.251 & 5.888 \\
\hline COCA (academic) & 0.394 & 0.07 & 5.648 \\
\hline $\begin{array}{l}\text { COCA (magazine \& } \\
\text { news) }\end{array}$ & 0.791 & 0.20 & 3.877 \\
\hline COCA (spoken) & 1.484 & 0.31 & 4.810 \\
\hline COCA (fiction) & 0.991 & 0.29 & 3.379 \\
\hline
\end{tabular}

Table 4 Good and bad in COCA

The results demonstrate that, in terms of the occurrences of these adjectives, MICASE is comparable to academic language if we consider both genders; however, when we look at the difference between the two genders, we notice that the proportion of good to bad is much higher among the females than for the males. In fact, the good/bad proportion among women speakers in MICASE is higher than for COCA (academic), which cannot be differentiated according to gender. This difference would be an interesting area for further research in broader contexts. Nevertheless, while it is tempting to focus only on this observable difference, it cannot be overlooked that both men and women prefer good to bad. Of course, this does not 
mean that contemporary American society is necessarily more positive adjectives than negative - as the results for good may include negative phrases such as good riddance, not good enough, etc. At the same time, bad can also be negated and has a positive slang meaning. This would also be an area worth studying.

\subsection{Big and small}

The table below (Table 5) presents the occurrences of big and small and their near synonyms in the MICASE corpus.

\begin{tabular}{|c|c|c|c|c|c|}
\hline \multirow[t]{2}{*}{ Adjective } & \multicolumn{2}{|l|}{ Males } & \multicolumn{2}{|l|}{ Females } & \multirow[t]{2}{*}{ P-value } \\
\hline & $\begin{array}{l}\text { raw } \\
\text { frequency }\end{array}$ & per 1000 & $\begin{array}{l}\text { raw } \\
\text { frequency }\end{array}$ & per 1000 & \\
\hline big & 378 & 0.481 & 464 & 0.510 & 0.3843 \\
\hline large & 174 & 0.221 & 191 & 0.210 & 0.6241 \\
\hline huge & 51 & 0.065 & 130 & 0.143 & 0.0001 \\
\hline tremendous & 24 & 0.031 & 32 & 0.035 & 0.5961 \\
\hline massive & 17 & 0.022 & 20 & 0.022 & 0.9601 \\
\hline Total 'big' & 644 & 0.819 & 837 & 0.921 & 0.0251 \\
\hline $\begin{array}{l}\text { Near } \\
\text { synonyms } \\
\text { total }\end{array}$ & 266 & 0.338 & 373 & 0.410 & 0.0160 \\
\hline small & 194 & 0.247 & 251 & 0.276 & 0.2380 \\
\hline short & 74 & 0.094 & 88 & 0.097 & 0.8572 \\
\hline limited & 53 & 0.067 & 49 & 0.054 & 0.2585 \\
\hline tiny & 36 & 0.046 & 28 & 0.031 & 0.1141 \\
\hline slight & 9 & 0.011 & 9 & 0.010 & 0.7566 \\
\hline miniature & 1 & 0.001 & 3 & 0.003 & 0.3898 \\
\hline Total 'small' & 366 & 0.465 & 425 & 0.468 & 0.9522 \\
\hline $\begin{array}{l}\text { Near } \\
\text { synonyms } \\
\text { total }\end{array}$ & 173 & 0.220 & 177 & 0.195 & 0.2543 \\
\hline
\end{tabular}

\section{Table 5 Bigand small}

Once again, we see that female speakers use most of these adjectives more often than men, but, with the exception of huge ( $\mathrm{p}=0.0001)$, these differences are not statistically significant. However, the difference between the total use of near synonyms of large between genders is not statistically significant. That said, when we compare the number of times near synonyms are used, it is interesting that women use near synonyms for big more often than men ( $\mathrm{p}=0.0160)$, whereas men use a greater variety of near synonyms for small than women. Although this latter difference is not statistically significant, it does run contrary to expectations and might be worth further analysis. 


\subsection{Pretty and ugly}

Table 6 presents the use of the adjectives pretty and ugly according to gender.

\begin{tabular}{|c|c|c|c|c|c|}
\hline \multirow[t]{2}{*}{ Adjective } & \multicolumn{2}{|l|}{ Males } & \multicolumn{2}{|c|}{ Females } & \multirow[t]{2}{*}{ P-value } \\
\hline & $\begin{array}{l}\text { per } \\
1000\end{array}$ & $\begin{array}{l}\text { raw } \\
\text { frequency }\end{array}$ & $\begin{array}{l}\text { per } \\
1000\end{array}$ & $\begin{array}{l}\text { raw } \\
\text { frequency }\end{array}$ & \\
\hline pretty & 445 & 0.566 & 434 & 0.477 & 0.0117 \\
\hline beautiful & 46 & 0.058 & 55 & 0.061 & 0.8650 \\
\hline cute & 4 & 0.005 & 20 & 0.022 & 0.0035 \\
\hline lovely & 12 & 0.015 & 10 & 0.011 & 0.4413 \\
\hline attractive & 12 & 0.015 & 8 & 0.009 & 0.2225 \\
\hline charming & 3 & 0.004 & 1 & 0.001 & 0.2501 \\
\hline Total 'pretty' & 519 & 0.660 & 527 & 0.580 & 0.0357 \\
\hline Near synonyms total & 77 & 0.098 & 94 & 0.103 & 0.7188 \\
\hline ugly & 12 & 0.015 & 9 & 0.010 & 0.3222 \\
\hline terrible & 21 & 0.027 & 24 & 0.026 & 0.9681 \\
\hline gross & 8 & 0.010 & 9 & 0.010 & 0.9522 \\
\hline disgusting & 3 & 0.004 & 8 & 0.009 & 0.2041 \\
\hline unpleasant & 3 & 0.004 & 5 & 0.006 & 0.6171 \\
\hline Total 'ugly' & 47 & 0.060 & 55 & 0.061 & 0.9522 \\
\hline Near synonyms total & 35 & 0.045 & 46 & 0.051 & 0.0588 \\
\hline
\end{tabular}

Table 6 Pretty and ugly

Keeping in mind the analyses of the previous tables, the number of occurrences of both pretty and ugly is interesting. Firstly, once again, the positive adjectives occur much more frequently than their negative counterparts. Secondly, several of the words occur more often in male speech than female speech, even if these differences are not always statistically significant.

Indeed, there are some surprising differences between male and female speech that warrant further investigation. At first glance, it appears that, apart from cute, men use pretty and its near synonyms more frequently than women do, whereas their use of ugly and its near synonyms are more or less equal. In particular, they use charming and lovely more often than women. Although this is not statistically significant, it does run contrary to expectations. Nevertheless, when it comes to pretty, a closer look at the corpus is necessary as the lexeme can function as both an adjective and an adverbial. Analyzing the concordance lines individually reveals that $99.1 \%$ of the male uses of the word are adverbial and could be glossed as rather. In terms of female usage, $96.1 \%$ are adverbial. When adjectival use is compared, woman use pretty more frequently than men and the difference is statistically significant $(\mathrm{p}=0.0121)$. 


\begin{tabular}{|l|l|l|l|l|l|}
\hline \multirow{2}{*}{ Adjective } & Males & Females & Males & Females & \multirow{2}{*}{ P-value } \\
\cline { 2 - 5 } & per $\mathbf{1 0 0 0}$ & raw frequency & per $\mathbf{1 0 0 0}$ & raw frequency & \\
\hline pretty & 4 & 0.005 & 17 & $\mathbf{0 . 0 1 9}$ & 0.0121 \\
\hline
\end{tabular}

Table 7 Adjectival use of pretty

This conforms with what we would expect from the literature review. The frequency of cute also conforms to expectations. In light of this, the comparative frequency of lovely, which, according to Lakoff (1973), women supposedly use more than men, stands out. Here the opposite trend is visible. Although the difference is not statistically significant, and limited to one particular genre, it does suggest that Lakoff's intuitions may have been off and more work should be done into the notion of 'feminine' or 'masculine' adjectives.

\subsection{Different and important}

Finally, in Table 8 we can see the occurrences of different and important and their near synonyms.

\begin{tabular}{|c|c|c|c|c|c|}
\hline \multirow[t]{2}{*}{ Adjective } & \multicolumn{2}{|l|}{ Males } & \multicolumn{2}{|l|}{ Females } & \multirow[t]{2}{*}{ P-value } \\
\hline & per 1000 & $\begin{array}{l}\text { raw } \\
\text { frequency }\end{array}$ & per 1000 & $\begin{array}{l}\text { raw } \\
\text { frequency }\end{array}$ & \\
\hline different & 952 & 1.210 & 1438 & 1.582 & 0.0001 \\
\hline various & 98 & 0.125 & 84 & 0.092 & 0.0434 \\
\hline unlike & 24 & 0.031 & 13 & 0.014 & 0.0244 \\
\hline distinct & 7 & 0.009 & 14 & 0.015 & 0.2301 \\
\hline contrasting & 4 & 0.005 & 3 & 0.003 & 0.5687 \\
\hline Total 'different' & 1085 & 1.380 & 1552 & 1.707 & 0.0001 \\
\hline $\begin{array}{l}\text { Near synonyms } \\
\text { total }\end{array}$ & 133 & 0.169 & 114 & 0.125 & 0.0188 \\
\hline important & 323 & 0.411 & 500 & 0.550 & 0.0001 \\
\hline significant & 50 & 0.064 & 56 & 0.062 & 0.8729 \\
\hline critical & 42 & 0.053 & 57 & 0.063 & 0.4295 \\
\hline crucial & 23 & 0.029 & 10 & 0.011 & 0.0071 \\
\hline essential & 9 & 0.011 & 16 & 0.018 & 0.2983 \\
\hline $\begin{array}{l}\text { Total 'impor- } \\
\text { tant' }\end{array}$ & 447 & 0.568 & 639 & 0.703 & 0.0006 \\
\hline $\begin{array}{l}\text { Near synonyms } \\
\text { total }\end{array}$ & 124 & 0.158 & 139 & 0.153 & 0.8026 \\
\hline
\end{tabular}

Table 8 Different and important

As was the case with the other results, we see that the basic adjectives are used more frequently by women than men, and these results are statistically significant 
$(\mathrm{p}=0.0001)$. Moreover, this continues to be the case when the near synonyms are also included, suggesting that perhaps female speakers feel a greater need to emphasize difference and importance. However, contrary to what has been suggested in the past or what has been seen with the other adjectives we have looked at so far, in the case of different, it is the male speakers rather than the female speakers who display greater linguistic dexterity, and this difference is statistically significant ( $\mathrm{p}=0.0188$ ). This gives reason to question whether the preference for variety is solely dependent on gender, or if it also depends on the type of word a speaker is looking for.

Moving on to important, the uses of crucial and critical demand further attention. Both are given as near synonyms in dictionary entries of the other, and Oxford Learner's Dictionary (https://www.oxfordlearnersdictionaries.com/) lists both as keywords, but only crucial is listed as an academic word. Moreover, in differentiating the two terms, the dictionary explains ' $[c]$ ritical is often used in technical matters of business or science; crucial is often used to talk about matters that may cause anxiety or other emotions'. Thus, stereotypes regarding male and female language use may prompt the conclusion that this difference is due to the fact that women choose critical for its emotional impact. However, that would ignore the fact that, in the context of the academy, critical takes on a variety of scientific definitions including '(a) a tendency to find and call attention to errors and flaws, (2) characterized by careful evaluation and judgement, (3) (chemistry and physics) at or of a point at which a property or phenomenon suffers an abrupt change especially having enough mass to sustain a chain reaction' (https://www.wordandphrase.info/).In addition, when both terms are checked on COCA's (Davies 2008-) academic word list, critical appears an average of 0.193 words per thousand and crucial 0.172 words per thousand. Thus, it is difficult to say whether the preference for critical over crucial is related to the gender of the speaker or is a characteristic of the academic genre. Also, once again it must be mentioned that both men and women prefer critical over crucial, which is in line with what could be expected from the COCA.

\section{Conclusion}

This paper analyzed the male and female use of eight basic adjectives and their near synonyms in the context of university life as made available by the MICASE corpus. The results presented above exemplify both similarities and differences in male/female adjective use. Some of the results add further support to previously observed tendencies in differences between male and female speech. For example, overall, women were recorded as using more of the studied adjectives than men. Moreover, they use pretty (adj.) and cute more often than males. However, there were also some surprises. For instance, men use lovely and marvelous more frequently than women. Moreover, while women in the corpus show greater linguistic 
dexterity when it comes to using near synonyms for good and big, men use more near synonyms for different. All of these values are statistically significant.

Not only does this study identify differences in male and female adjective use, but also points to a number of similarities. Firstly, of the adjectives chosen for this analysis, good and different are used most frequently by both men and women. Secondly, both genders tend to use positive adjectives more than negative adjectives. Thirdly, males and females use ugly (and its near synonyms) and small (and its near synonyms) in equal proportions. The results for bad (and its near synonyms) show only a slight difference. Finally, for the most part, the basic adjectives are used much more frequently than their near synonyms. Deviations from the norm are bad (among male speakers) and pretty (adj.). Regarding the latter, when only the adjective forms were counted, beautiful becomes the most frequent for both sexes.

The mixed results of this study, although limited to one genre, do suggest that Lakoff's intuitions, and the stereotypes they represent, do not always hold and more work should be done into the notion of 'feminine' or 'masculine' adjectives.

\section{References}

Amir, Zaini, Hazirah Abidin, Saadiyah Darus, and Kemboja Ismail (2012). Gender Differences in The Language Use of Malaysian Teen Bloggers. GEMA Online ${ }^{\mathrm{TM}}$ Journal of Language Studies 12(1): 105-124

Baker, Paul (2014). Using corpora to analyze gender. London, New York: Bloomsbury

Bamman, David, Jacob Eisenstein, and Tyler Schnoebelen (2014). Gender identity and lexical variation in social media. Journal of Sociolinguistics 18(2): 135-160. https://www.doi.org/\%2010.1111/josl.12080

Bucholtz, M. (2004) Editor's Introduction. Lakoff, Robin. T., and Mary Bucholtz, eds. Language and Woman's Place: Text and Commentaries. Oxford: Oxford University Press, 3-14

Butler, Judith (1990). Gender trouble: Feminism and the subversion of identity. New York: Routledge

Cameron, Deborah (2005). Language, Gender, and Sexuality: Current Issues and New Directions. Applied Linguistics 26(4): 482-502

Cameron, Deborah (2008). The Myth of Mars and Venus. Oxford: Oxford University Press

Chambers, J. K., and Natalie Schilling-Estes (eds.) (2013). The handbook of language variation and change. Wiley-Blackwell

Davies, Mark (2008-). The Corpus of Contemporary American English (COCA): 560 million words, 1990-present. Available at https://corpus.byu.edu/coca/

Eckert, Penelope, and Sally McConnell-Ginet (2002). Language and gender. Cambridge: Cambridge University Press

Gu, Lihong (2013). Language and Gender: Differences and Similarities. 2013 International Conference on Advances in Social Science, Humanities, and Management (ASSHM 2013): 248-251 
Haas, Adelaide (1979). Male and Female Spoken Language Differences: Stereotypes and Evidence. Psychological Bulletin 86(3): 615-626

Hartman, Maryann (1976). A Descriptive Study of the Language of Men and Women Born in Maine around 1900 As It Reflects the Lakoff Hypotheses in "Language and Women's Place". Paper presented at the Conference on the Sociology of the Languages of American Women. New Mexico State University, Las Cruces, New Mexico, January 16-17, 1976. Available online at https://files.eric.ed.gov/fulltext/ED130316.pdf

Herring, Susan C., and Sanja Kapidzic (2015). Teens, Gender, and Self-Presentation in Social Media. J. D. Wright, ed. International Encyclopedia of Social \& Behavioral Sciences. Oxford: Elsevier, 146-152

Holmes, Janet (1997). Women, Language and Identity. Journal of Sociolinguistics 1(2): 195223. https://doi.org/10.1111/1467-9481.00012

Huffaker, David A., and Sandra L. Calvert (2005). Gender, Identity, and Language Use in Teenage Blogs. Journal of Computer-Mediated Communication 10(2): 1-23. https://doi.org/10.1111/j.1083-6101.2005.tb00238.x

Hyde, Janet Shibley (2005). The gender similarities hypothesis. The American Psychologist 60 (6): 581-592. https://doi.org/10.1037/0003-066X.60.6.581

Jay, Kristin L., and Timothy B. Jay (2013). A Child's Garden of Curses: A Gender, Historical, and Age-Related Evaluation of the Taboo Lexicon. The American Journal of Psychology 126(4): 459-475. https://doi.org/10.5406/amerjpsyc.126.4.0459

Lakoff, Robin T. (1975). Language and woman's place. New York: Harper \& Row

Lakoff, Robin T., and Mary Bucholtz (eds.) (2004). Language and Woman's Place: Text and Commentaries. Oxford: Oxford University Press

Kramer, Cheris (1974). Women's Speech. Separate but Unequal? Quarterly Journal of Speech 60(1): 14-24. https://doi.org/10.1080/00335637409383203

MacGeorge, Erina L., Angela R. Graves, Bo Feng, Seth J. Gillihan, and Brant R. Burleson (2004). The Myth of Gender Cultures: Similarities Outweigh Differences in Men's and Women's Provision of and Responses to Supportive Communication. Sex Roles 50(34): 143-175. https://doi.org/10.1023/B:SERS.0000015549.88984.8d

Paoletti, Jo B. (2012). Pink and blue: Telling the boys from the girls in America. Bloomington: Indiana University Press

Queen, Robin (2013). Gender, Sex, Sexuality, and Sexual Identities. Chambers, J. K., and Natalie Schilling-Estes, eds. The Handbook of Language Variation and Change. WileyBlackwell, 368-387. https://doi.org/10.1002/9781118335598.ch17

Römer, Ute (2010). CoRD: Michigan Corpus of Academic Spoken English. http://www.helsinki.fi/varieng/CoRD/corpora/MICASE/index.html

Schilling-Estes, Natalie, and Walt Wolfram (1998). American English: Dialects and Variation. Oxford: Blackwell Publishing

Schmid, H.-J. (2003). Do women and men really live in different cultures? Evidence from the BNC. Wilson, Andrew, Paul Rayson, and Tony McEnery, eds. Corpus Linguistics by the Lune: A Festschrift for Geoffrey Leech. Frankfurt am Main u. a.: Lang, 185-221 
Simpson, R. C., Briggs, S. L., Ovens, J., and Swales, J. M. (2002) The Michigan Corpus of Academic Spoken English.

https://quod.lib.umich.edu/cgi/c/corpus/corpus?c=micase;page=simple

Swales, J. M. (2006). Corpus Linguistics and English for Academic Purposes. Arnó Macià, Elisabet, Antonia Soler Vercera, and Carmen Rueda Ramos, eds. Information technology in languages for specific purposes: Issues and prospects. New York: Springer, 19-33

Tannen, Deborah (1990). You just don't understand: Women and men in conversation. New York: Morrow

Vandergriff, Jim (1984). Is There a Women's Language? Available at: http://faculty.knox.edu/jvanderg/Women\%27s\%20English.html

Wardhaugh, Ronald (2006). An Introduction to Sociolinguistics. Oxford: Blackwell Publishing

\section{Good or marvelous? Pretty, cute or lovely? Upotreba pridjeva među govornicima i govornicama u korpusu MICASE}

Gotovo pedeset godina prošloje od izlaska kontroverznoga izdanja Robin Lakoff Language and a Woman's Place (1975), a još uvijek nema jasna odgovora na pitanje koji je odnos (ako on postoji uopće) između jezika i roda (v. Baker 2014: 3, Cameron 2005). Dosadašnje teorije koje se bave sličnostima i razlikama između muškoga i ženskoga govora najčešće su usredotočene na društveni i kulturni utjecaj koji može potaknuti muškarca ili ženu da se na određeni način ponašaju ili govore, npr. da upotrebljavaju više pridjeva ili da upotrebljavaju širi raspon pridjeva. Nadalje, te teorije često upotrebljavaju anegdote i osobne informacije kao izvor podataka, što rezultira istraživanjima, a onda i člancima, na čiju provedbu i pisanje utječe intuicija istraživača (Baker 2014; Schmid 2003). Tek je u posljednjih petnaest do dvadeset godina postalo moguće analizirati velike baze govornih podataka kako bi se testiralo spomenutu intuiciju. Ipak, rezultati se i dalje mogu različito tumačiti, unatoč računalnoj analizi podataka. Cilj je ovoga rada analizirati kako govornici i govornice upotrebljavaju pridjeve u korpusu Michigan Corpus of Academic Spoken English (MICASE). Usporedit ćemo upotrebu odabranih pridjeva (good, bad, big, small, pretty, ugly, important i different) i njihovih sinonima kako bismo podržali ili doveli u pitanje tvrdnje temeljene na intuiciji o tome da su određeni pridjevi više 'ženski' odnosno više 'muški', ili da žene upotrebljavaju više pridjeva ili širi raspon pridjeva nego muškarci. Nadamo se da će ovaj rad pridonijeti raspravi o rodnim razlikama i jeziku.

Keywords: use of adjectives, men's speech, women's speech, gender differences in language, MICASE Ključne riječi: upotreba pridjeva, muški govor, ženski govor, rodne razlike u jeziku, MICASE 